\title{
THE INTERPLAY OF READING ANXIETY, READING STRATEGY USE AND ACADEMIC ACHIEVEMENT OF NON-ENGLISH MAJORED STUDENTS AT A UNIVERSITY IN THE NORTH OF VIETNAM
}

\author{
Le Quang Dung* \\ International School, Thai Nguyen University \\ Tan Thinh, Thai Nguyen, Vietnam
}

Received 12 May 2020

Revised 11 August 2020; Accepted 29 November 2020

\begin{abstract}
A quantitative research was carried out at the International School, Thai Nguyen University to measure the levels of reading anxiety among non-English majored students who had just finished one year of intensive English. These students were supposed to take a simulation IELTS exam with an expected result of 5.5 overall bands (B2-CEFR). The finding showed that the level of anxiety measured was at medium level $(\mathrm{M}=3.31, S D=0.59, \mathrm{SEM}=0.09, \mathrm{Min}=2.05, \mathrm{Max}=4.30$, Skewness $=-0.46, \mathrm{Kurtosis}=-0.54)$. The second research question focuses on the correlation between reading anxiety and the use of reading strategies. The results showed that there was no significant difference between reading anxiety and the uses of reading strategies. The third research finding indicated that there was a significant difference between the levels of reading anxiety and academic reading achievement. Students with high level of anxiety attain low achievement. Low anxiety $(M=2.64, S D=0.50)$ was significantly larger for High anxiety $(M=1.40, S D=0.52)$.
\end{abstract}

Keywords: interplay, reading anxiety, reading strategies, high anxiety, low achievement.

\section{Introduction}

\subsection{Background to the study}

Reading academic texts at universities poses great challenges to most students. Firstly, it requires the involvement of many strategies simultaneously to understand what has been written by authors. The effective use of strategies assists students in accomplishing certain language tasks more successfully. Learners with a large repertoire of reading strategies perform better (Anderson, 2005; Nagy \& Habók, 2018). Secondly, the readers must be able to control themselves from psychological problems such as anxiety or apprehension while reading, especially during reading tests.

\footnotetext{
*Tel.: +84 913547905, Email: dunglq@tnu.edu.vn
}

Undoubtedly, reading is one of the most crucial language skills serving as the foundation for other language skills to develop, especially for academic writing at tertiary level. It is thought to be the primary means for gaining access to various sources of information, providing the basis for "synthesis and critical evaluation skills" (Celce-Murcia, 2001, p. 187).

Reading academic texts is far beyond the for-pleasure readings. It is the process of extracting meaning from written texts. Carrell (1998) refers to reading comprehension as the interaction between knowledge existing in a learner's mind (prior knowledge) and the new knowledge from the information being read in the text; it takes the use of strategies in reading, and the readers' awareness in monitoring their 
comprehension and in using appropriate strategies to deal with their problems in comprehending texts. Crème (2008, p. 55) shares an idea that readers are required to have great efforts and strategies to comprehend because ideas are embedded in the text and it can take a lot of re-reading to unravel them so that they appear clear and understandable. In the same view, Yukselir (2014) considers reading comprehension as a result of a complicated process between a number of elements such as text, setting, reader background, and reading strategies.

Numerous studies have been done to investigate the importance of reading strategies. However, a psychological factor that is believed to hamper readers from successfully comprehending a written text, especially in a reading examination, has likely been left out, which is the foreign language reading anxiety, especially in Vietnamese foreign language teaching context. That is the reason why the present study attempts to investigate the interplay between reading strategy uses, reading anxiety and reading achievement among foreign language students at Thai Nguyen University. The reading anxiety, reading strategy use are treated as factors (independent variables) that affect the reading achievement outcomes which are referred to as a dependent variable.

\subsection{Aims of the study}

The present study was conducted with the following aims; (1) to investigate the levels of anxiety that English learners may experience during a reading examination, (2) to examine the relationship between reading anxiety and the uses of reading strategies for better comprehension, finally (3) to explore the correlation between students' reading anxiety and reading achievements.

\subsection{Research questions}

In responding to the above mentioned aims, the study is supposed to answer the following research questions:

- What is the level of reading anxiety among non-English majored students at Thai Nguyen University?

- What is the correlation between reading anxiety and reading strategy use?

- What is the relationship between reading anxiety and reading achievement?

\subsection{Significance of the study}

The findings from the study firstly fill in the gaps of literature in terms of language anxiety, the uses of reading strategies and the academic reading achievements of the non-English majored students in the context of teaching and learning English in Vietnam. Besides, teachers who teach academic reading might use the findings as references to develop activities to lower negative impacts of language anxiety as well as better comprehend teaching practices.

\section{Literature review}

\subsection{Language anxiety (LA)}

The science of language learning and teaching is closely connected to studies of psychology. In other words, psychologists have defined many phenomena in language teaching and learning practices. Psychologically, anxiety is defined as the subjective feeling of tension, apprehension, nervousness, and worry that are experienced by an individual, and the heightened activity of the autonomic nervous system that accompanies these feelings (Spielberger, 1976, p. 5). The more 
recent definition of anxiety by Zeidner states that anxiety refers to a psychological state in which the person's sense of uneasy suspense and worry is triggered by ambiguous circumstances (Zeidner, 2010, p. 5). Zeidner distinguishes the confusing term "anxiety" from "fear" which refers to an intense biologically adaptive physiological and behavioural response to the occurrence of a specific, identifiable stimulus. In other words, fear is objective, clear, and in the present, while anxiety is subjective, ambiguous and relates to future danger (p. 6).

Language anxiety can be defined as "a distinct complex of self-perceptions, beliefs, feelings, and behaviours related to classroom language learning arising from the uniqueness of the language learning process" (Horwitz, Horwitz, \& Cope, 1986, p. 128). Longman Dictionary defines language anxiety as subjective feelings of apprehension and fear associated with language learning and use (Richards, 1985, p. 313).

Explicitly, anxiety is the automatic reaction of the nerve system when confronting unfamiliar situations or events. Naturally, the feeling seriously affects language performance of language users. The relationship between anxiety and performance can best be illustrated with an inverted " $U$ ", that is, "when anxiety is low, performance is also low. When anxiety is optimal, performance is high, but beyond an optimal level of anxiety, performance deteriorates" (Walker, 1997, p. 17). Numerous studies have found that anxiety has debilitating effects on the language learner and was said to be one of the strongest predictors of success in language learning (McIntrye, 1999). Gardner and MacIntyre (1993) shared a definition of foreign language anxiety (FLA) as a fear or apprehension occurring when a learner is expected to perform in a second or foreign language. Horwitz et al. (1986) concluded that foreign language anxiety frequently shows up in listening and speaking activities, testing situations, over-studying, and so on. Anxiety has also been a major concern in many other spheres, as shown in such phrases as computer anxiety, sport anxiety, social anxiety... In terms of language learning and teaching, the concept of 'reading anxiety' was first introduced by Saito and her colleagues. She developed the Foreign Language Reading Anxiety Scale (FLRAS) which has been used to measure foreign language anxiety levels in reading comprehension (Saito, Garza, \& Horwitz, 1999).

\subsection{Reading anxiety and reading achievement}

The concepts of LA and FLA had been the basis for many related inventories such as Foreign Language Speaking Anxiety (FLSA), Foreign Language Listening Anxiety (FLLA), Foreign Language Classroom Anxiety Scale (FLCAS) and Daly-Miller Writing Apprehension Test (SLWAT). Reading skill has long been seen as less interpersonal interaction in comparison with other skills like speaking and listening which contain more anxiety provoking factors. However, research confirms that reading anxiety does exist when second or foreign language learners have to cope with reading passages (Saito et al., 1999). Saito highlighted the reading anxiety which emerges from text processing rather than reading difficulty. The primary focus of the study was on the cognate of the languages. Basing on the findings from levels of anxiety of learners whose native language was French which has many cognates to English (both languages use the Roman alphabet), Russian which has few cognates and Japanese which is completely non-cognate to English, Saito et al. developed an instrument (FLRAS) that is claimed capable of measuring levels 
of reading anxiety in both unfamiliar orthographic and cultural diversities, i.e. both different writing system and content (Zoghi, 2012). The introduction of the FLRAS was seen as the compensation for the paucity in the literature of language anxiety. Despite many arguments around Saito et al.'s (1999) hypotheses about foreign language reading anxiety (Spark, Ganschow, \& Javorsky, 2000), FLRAS has been utilized in various studies in several countries, especially in China. Chen (2005) investigated foreign language reading anxiety among 46 Year-1 non-English majors and concluded that these participants demonstrated a high level of reading anxiety which was negatively correlated to an indicator of their English achievement, especially for the females. Shi and Liu (2006) studied 211 Year-2 non-English majors. The findings showed that Chinese university students' FL reading anxiety was negatively correlated to both their College English Test Band-4 (CET-4) overall grades and their reading comprehension grades. The findings also indicated that male students demonstrated remarkably higher reading anxiety but lower English achievements than female students. Qiu and Liao (2007) carried out a study with 153 non-English majors and found that foreign language reading anxiety was caused by examoriented reading practice. The findings also revealed that reading anxiety was negatively correlated to foreign language proficiency. More than that, reading anxiety could predict male students' English proficiency much better than it did that of females. Wang and Fang's (2008) findings indicated that reading anxiety was significantly negatively correlated to both reading performance and reading strategy use while the latter two were significantly positively correlated to each other. Capan and Karaca (2012) examined the relationships among gender, education level and language anxiety, associated with two major language skills: listening and reading. The subject was 159 EFL students at a Turkish University. The results revealed moderate correlations between education level and reading anxiety.

\subsection{Reading strategy and academic achievement}

Reading strategies are defined as 'the mental operations or comprehension processes that readers select and apply in order to make sense of what they read' (Abbott, 2006, p. 637). Readers' strategy use while reading demonstrates their interaction with written texts, and effective use of strategies can improve their reading efficiency and text comprehension (Carrell, 1989). Anderson (1991) posits that reading strategies are deliberate, cognitive steps that readers can take to assist in acquiring, storing and retrieving new information. Williams and Burden (1997) further classifies reading strategies as cognitive, metacognitive and social strategies which deal with (a) efficient retrieval, storage, and acquisition of information for readers to extract and construct meaning from texts, (b) readers' knowledge of cognitive resources, awareness of cognitive processing, and the ability to adjust utilized strategies and (c) "asking for clarification or verification," "cooperating with peers and proficient users of the new language," "developing cultural understanding," and "becoming aware of others' thoughts and feelings respectively".

According to Long and Crookes (1992, p. 42) formal instruction on strategies has a positive effect on students' use of strategies and improves the rate of learning. However, strategies should be contextualized for the purpose of the formal training. Decontextualized teaching of individual strategies for a short time will not have a long 
term effect on students nor will it help them to develop as strategic readers. Strategy use develops over a long term, perhaps several years. In this regard, Janzen (2002, p. 288) introduces the following factors in the formal instruction of strategies to help develop learners into strategic readers:

- Inserting strategies in the content area of students' regular course;

- Teaching strategies through direct explanation, teacher modeling, and feedback;

- Recycling the strategies over new texts and tasks.

Teaching strategies become more useful if it is related to the reading task at hand, if it fits the particular student's learning style preferences to one degree or another and if students employ the strategy effectively and link it with other relevant strategies (Oxford, 2001, p. 362). Strategies that fulfill these conditions make learning easier, faster, more enjoyable, more self-directed, more effective, and more transferable to new situations. Application of learning strategies can facilitate internalization, storage, or retrieval of new information. The ability to employ strategies during reading distinguishes good readers from poor ones. Good readers use strategies in a systematic way whereas poor ones use them in a random, unconnected, and uncontrolled manner. Good readers are also able to shift between alternative strategies, as needed, so that they can progress in reading as efficiently as possible (Vann \& Abraham, 1990). Strategy training can be generally included in academic courses. Therefore, by creating proper situations, students can have opportunities to use, adapt, evaluate, and transfer a strategy to new situations and in reading tasks. Besides, providing suitable contexts for strategy instruction can encourage teachers to model reading skills and strategies overtly, facilitating students' performances of these abilities. However, strategies should be learned in an organized way. The organized, reasoned use of learning strategies is more important than the sheer frequent use of them. Successful application of strategies helps readers to process a text actively, to monitor their comprehension, and to connect what they are reading to their own existing knowledge and to other parts of the text.

Reading is the primary source for getting different information. It is important for learning as it gives learners independent access to a vast world of information as well as fulfillment and enjoyment (Gunning, 2007 , p. 3). To Schmidt, Rozendal \& Green (2002, p. 131), the ability to read is a critical component of school success and a strong correlation exists between poor reading ability and school failure. Reading is essential for learning and if learners have not properly mastered the skill their potential for success in the learning context is hampered (Bohlman \& Pretorius, 2002, p. 205; Martin \& Carvalho, 2008, p. 114).

The success or failure in reading depends greatly on the strategies used by readers. In other words, readers are required to manipulate various tasks in order to comprehend a written text. Johnston (1983) asserts that

Reading comprehension is considered to be a complex behavior which involves conscious and unconscious use of various strategies, including problem-solving strategies, to build a model of the meaning which the writer is assumed to have intended. The model is constructed using schematic knowledge structures and the various cue systems which the writer has given (e.g., words, syntax macrostructures, social information) to generate hypotheses which are tested using 
various logical and pragmatic strategies. Most of this model must be inferred, since text can never be fully explicit and, in general, very little of it is explicit because even the appropriate intentional and extensional meanings of words must be inferred from their context. (p. 17)

Gunderson (2014) provides explanations for the three levels of comprehension: literallevel comprehension requires little more than simple memory work and the remembering of details from the text; inferential-level comprehension involves "readers in thinking about what they've read and coming to conclusions that go beyond the information given in the text"; at critical and evaluativelevel comprehension, readers are able to "evaluate whether a text is valid and expresses opinion rather than fact, as well as apply the knowledge gained from the text in other situations" (p. 28).

\section{Methodology}

\subsection{Participants}

The participants were 48 second year students of English as a foreign language at Thai Nguyen University of Education. These students have just finished one year of intensive English. In the second year, they will be required to take an IELTS exam and score an overall band of 5.5 (B2-CEFR) to be accepted in the second phase of their 4 year program.

\subsection{Data collection instruments}

In order to measure the levels of reading anxiety, the Foreign Language Reading Anxiety Scale (FLRAS) developed by Saito et al. (1999) was used to assess students' reading anxiety. The FLRAS consists of 20 items which consists of five-points Likert Scale, ranging from five points "strongly agree" to one point "strongly disagree." To score each item in a questionnaire depends on the negative wording or positive wording. The internal consistency of FLRAS was $0.982(\mathrm{~N}=20)$.

The Survey of Reading Strategies (SORS) designed by Mokhtari and Sheorey (2002) was used to investigate learners' choice of strategies while reading English. SORS consists of 30 items on a five-point Likert Scale, ranging from one point (I never or almost never do this) to five points (I always or almost always do this). The internal consistency of SORS was 0.768 $(\mathrm{N}=30)$ (see appendices).

The academic achievement of the participants is measured by their results of the IELTS-simulation test. The researcher extracted the results of the reading module of the participants to use as a variable in the study. The participants were graded as high achievers (7.0-8.0); medium achievers (5.0$6.5)$ and low achievers (3.0-4.5).

\subsection{Data analysis instruments}

The SPSS version 20 was used to analyse the data for the present study.

\section{Findings}

\subsubsection{RQ1: What is the level of reading anxiety among EFL students at Thai Nguyen University?}

The observations for FLRAS had an average of $3.31(\mathrm{SD}=0.59$, $\mathrm{SEM}=0.09$, $\operatorname{Min}=2.05, \operatorname{Max}=4.30$, Skewness $=-0.46$, Kurtosis $=-0.54)$. When the skewness is greater than 2 in absolute value, the variable is considered to be asymmetrical about its mean. When the kurtosis is greater than or equal to 3 , then the variable's distribution is markedly different from a normal distribution in its tendency to produce outliers (Westfall \& Henning, 2013). The summary statistics can be found in Table 1.1. 
Table 1.1 Summary Statistics Table for Interval and Ratio Variables

\begin{tabular}{ccccccccc}
\hline Variable & $M$ & $S D$ & $n$ & $S E_{M}$ & Min & Max & Skewness & Kurtosis \\
\hline FLRAS & 3.31 & 0.59 & 48 & 0.09 & 2.05 & 4.30 & -0.46 & -0.54 \\
\hline
\end{tabular}

4.1.2. RQ2. What is the correlation between reading anxiety and reading strategy use?

A Pearson correlation analysis was conducted between FLRAS and SORS. Cohen's standard was used to evaluate the strength of the relationship, where coefficients between .10 and .29 represent a small effect size, coefficients between .30 and .49 represent a moderate effect size, and coefficients above .50 indicate a large effect size (Cohen, 1988).

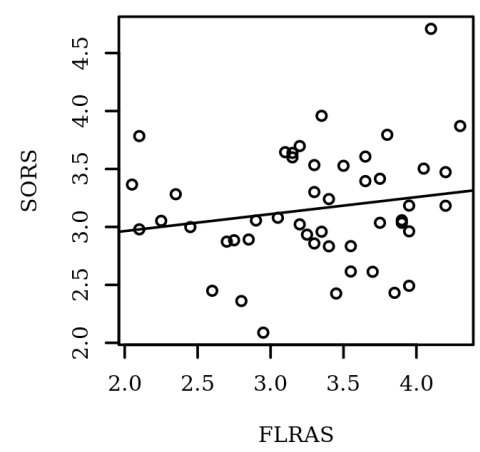

\section{Assumptions}

Linearity. A Pearson correlation requires that the relationship between each pair of variables is linear (Conover \& Iman, 1981). This assumption is violated if there is curvature among the points on the scatterplot between any pair of variables. Figure 1 presents the scatterplot of the correlation. A regression line has been added to assist the interpretation.

Table 2.1 Pearson Correlation Results between FLRAS and SORS

\begin{tabular}{cccc}
\hline Combination & $r_{\mathrm{p}}$ & $95 \% \mathrm{CI}$ & $p$ \\
\hline FLRAS-SORS & 0.18 & {$[-0.11,0.44]$} & .229 \\
\hline
\end{tabular}

\subsubsection{RQ3. What is the relationship between reading anxiety and reading achievement?}

An analysis of variance (ANOVA) was conducted to determine whether there were significant differences in Reading Achievement (RA) by FLRAS.

\section{Assumptions}

Normality. The assumption of normality was assessed by plotting the quantiles of the model residuals against the quantiles
Figure 2.1 Scatterplots between each variable with the regression line added

\section{Results}

The result of the correlation was examined based on an alpha value of 0.05 . There were no significant correlations between any pairs of variables. Table 3 presents the results of the correlation.

of a Chi-square distribution, also called a Q-Q scatterplot (DeCarlo, 1997). For the assumption of normality to be met, the quantiles of the residuals must not strongly deviate from the theoretical quantiles. Strong deviations could indicate that the parameter estimates are unreliable. Figure 3.1 presents a Q-Q scatterplot of model residuals. 


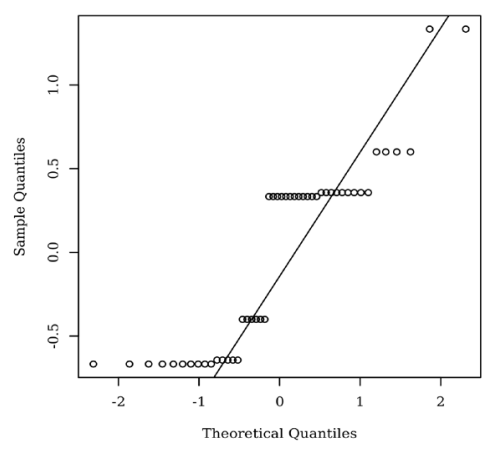

Figure 3.1 Q-Q scatterplot for normality of the residuals for the regression model.

Homoscedasticity. Homoscedasticity was evaluated by plotting the residuals against the predicted values (Bates et al., 2014; Field, 2013; Osborne \& Walters, 2002). The assumption of homoscedasticity is met if the points appear randomly distributed with a mean of zero and no apparent curvature. Figure 3.2 presents a scatterplot of predicted values and model residuals.

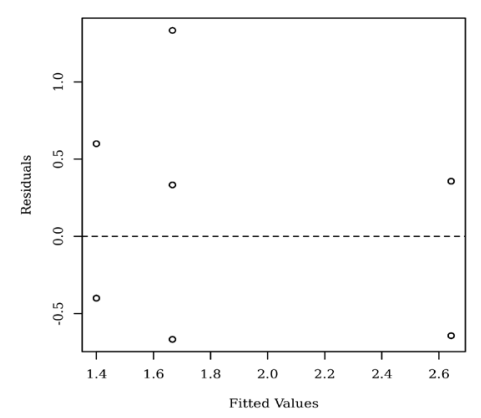

Figure 3.2 Residuals scatterplot testing homoscedasticity

Outliers. To identify influential points, Studentized residuals were calculated and the absolute values were plotted against the observation numbers (Field, 2013; Stevens, 2009). Studentized residuals are calculated by dividing the model residuals by the estimated residual standard deviation. An observation with a Studentized residual greater than 3.27 in absolute value, the 0.999 quartile of a $t$ distribution with 47 degrees of freedom, was considered to have significant influence on the results of the model. Figure 3.3 presents the Studentized residuals plot of the observations. Observation numbers are specified next to each point with a Studentized residual greater than 3.27.

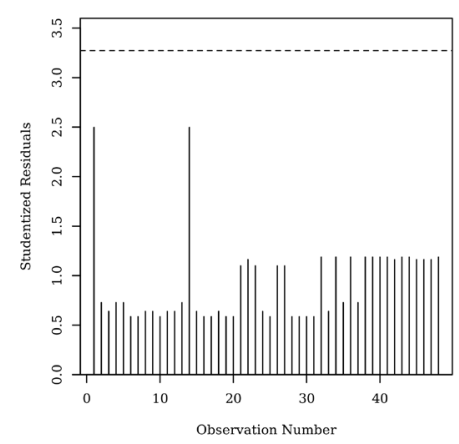

Figure 3.3 Studentized residuals plot for outlier detection

\section{Results}

The ANOVA was examined based on an alpha value of 0.05 . The results of the ANOVA were significant, $\mathrm{F}(2,45)=17.36, \mathrm{p}<.001$, indicating there were significant differences in RA among the levels of FLRAS (Table 3.1). The eta squared was 0.44 indicating FLRAS explains approximately $44 \%$ of the variance in RA. The means and standard deviations are presented in Table 3.2.

Table 3.1 Analysis of Variance Table for RA by FLRAS

\begin{tabular}{cccccc}
\hline Term & $S S$ & $d f$ & $F$ & $p$ & $\eta_{\mathrm{p}}^{2}$ \\
\hline FLRASR & 11.53 & 2 & 17.36 & $<.001$ & 0.44 \\
Residuals & 14.95 & 45 & & & \\
\hline
\end{tabular}




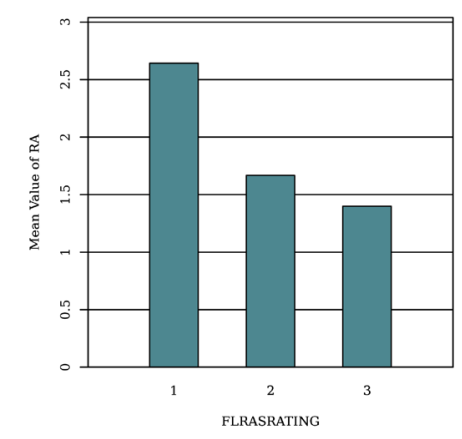

Figure 3.4 RA Means by factors levels of FLRAS

Table 3.2 Mean, Standard Deviation, and Sample Size for RA by FLRAS

\begin{tabular}{cccc}
\hline Combination & $M$ & $S D$ & $n$ \\
\hline Low anxiety & 2.64 & 0.50 & 14 \\
Medium anxiety & 1.67 & 0.64 & 24 \\
High anxiety & 1.40 & 0.52 & 10 \\
\hline
\end{tabular}

\section{Post-hoc}

Paired t-tests were calculated between each pair of measurements to further examine the differences among the variables. Tukey pairwise comparisons were conducted for all significant effects based on an alpha of 0.05. For the main effect of FLRAS, the mean of RA for $1(\mathrm{M}=2.64, \mathrm{SD}=0.50)$ was significantly larger than for $2(\mathrm{M}=1.67, \mathrm{SD}=0.64)$, $\mathrm{p}<.001$. For the main effect of FLRAS, the mean of RA for Low anxiety $(\mathrm{M}=2.64$, $\mathrm{SD}=0.50)$ was significantly larger than for High anxiety $(\mathrm{M}=1.40, \mathrm{SD}=0.52), \mathrm{p}<.001$. No other significant effects were found.

\section{Discussions}

The first objective of the present study was to examine the levels of reading anxiety experienced by 48 non-English majored students at Thai Nguyen University. These students had been intensively studying for the IELTS examination to be placed in their major studies. It is assumed that the reading module is the most challenging paper in the exam. Many students even have phobia as they come across the reading module. Research into the factors that contribute to reading performance decrement in second language reading among university students has shown that anxiety can hinder comprehension by interfering with the readers' cognitive systems which are responsible for processing the information in the reading texts. It appears that anxious readers are most likely to experience interference with their cognitive ability resulting in deficits in their comprehension performance. As has been defined, foreign language reading anxiety can be the feelings of frustration and apprehension one experiences when he fails comprehending a text in the target language. Although it may be true that at first glance, reading is perceived as a less anxiety-provoking activity in that it is fundamentally an individual task and allows for reconsideration (Saito et. al., 1999, p. 202), there is still a sense of threat, which triggers anxiety in learners of any foreign language. More specifically, reading anxiety is aggravated in foreign language contexts as it requires readers to activate certain cognitive 
processes including attention, perception, memory and comprehension (Sellers, 2000). Hence, anxiety is seen to play a role in influencing comprehension performance among the non-English majored learners. For the present study, in responding to the first research question "What is the level of reading anxiety among EFL students at Thai Nguyen University? The result of the study showed that the participants experienced reading anxiety at medium level $(\mathrm{M}=3.31, \mathrm{SD}=$ 0.59 ). This is partly because they did not have chances to read academic passages at schools. The reading tasks that they have to deal with at universities are too much beyond their ability in both length and academic issues, especially when they must do the IELTS reading module with three reading passages under time pressure. Those who came up to the IELTS for the first time would find the reading module challenging. A minority of the participants who showed a low level of reading anxiety are those who have been familiar with long reading passages before entering universities. These results coincide with those from a number of previous studies about language reading anxiety (e.g. Sari, 2017; Wu, 2015, Ghonsooly, 2012; Murad et al., 2013).

The second objective of the study was to explore the relationship between reading anxiety and the use of reading strategy. It is believed that successful language learners are described in terms of the acquisition of rules and principles. However, acquiring the rules and principles is insufficient and there are other possible factors besides linguistic acquisition that could contribute to the success of language learning such as affective factors which some psychologists and linguists have attributed to (Schumann, 1987). Language learning strategies are referred to as tactics that readers use deliberately when routine techniques are inadequate to resolve a given interpretation (Anderson, 1991; Carrell, 1998; Paris et al., 1991). Strategies are, thus, employed differently because the unique nature of each text requires readers to modify strategies to fit the demands of the text (Duffy, 1993). If strategies are conscious actions that can be controlled by readers, they are used selectively and in combination (Carrell, 1998; Paris et al., 1991). It is worth considering impacts of reading anxiety over the uses of reading strategies when dealing with reading texts. For the present study, in responding to the second research question "What is the correlation between reading anxiety and reading strategy uses? The result of the study indicated that there was no correlation between foreign language reading anxiety level and the uses of a variety of reading strategies as a whole or with reading strategies separately. This can be explained as the uses of reading strategies in the reading practice might be different from those in the examination. Many students reported that they use a variety of strategies while doing reading practice, however, during a real examination they cannot use any of the learnt strategies. Many studies have been conducted to examine the possible relationship between reading anxiety, reading strategies and its interference on second language learning and language performance (Aida, 1994; Horwitz et al., 1986; MacIntyre \& Gardner, 1989; Sellers, 2000; Scovel, 1978; Young, 1986). The finding from this study is similar to the situations of some Asian countries such as Indonesian and Filipino EFL learners in the studies conducted by Wardah and Jerryk (2018) and Wilta (2017).

The final objective of the study was to examine the relationship between reading anxiety and reading achievement. Anxiety reactions, characterized by worrisome thoughts about the impending reading tests, 
will most likely lead to the occurrence of self-preoccupation and other task irrelevant thoughts which interfere with their cognitive systems required for processing the information in the text. Anxious individuals usually experience division in their attention between the demand of the task and the preoccupation of negative thoughts (Tobias, 1979). Hence, comprehension performance is likely to suffer whenever the subjects' attention interferes with the reading anxiety reactions which in turn tax the functions of the working memory (Downing \& Leong, 1982). Text level processes make a greater demand on these two components, i.e. attention and working memory (Haberlandt \& Graesser, 1985). Any interference among these components may hinder the readers from processing and retrieving the information in the text (Bell \& Perfetti, 1994; Just \& Carpenter, 1992). For the present study, in responding to the third research question "What is the relationship between reading anxiety and reading achievement?, the findings of the study showed that there is a significant difference between the levels of reading anxiety and the reading academic achievement among the participants of the study. The higher level of reading anxiety, the lower points in reading achievement they can attain. This is because the overanxious feeling hampered the comprehension process. The results were congruent with some studies conducted in Asian countries and in the world (Murad et al., 2013; Manoochehr, 2012; Abbas, 2014; Farveh et al., 2014).

\section{Conclusions and pedagogical implications}

In conclusion, the present study examines levels of anxiety experienced by non-English majored students at Thai Nguyen University. The students are required to attain 5.5 in the IELTS examination. Most of the students reported that the reading paper is the most difficult part. They even get phobia of the length and difficulty of the paper. The findings reveal that the participants experienced reading anxiety at medium level $(\mathrm{M}=$ $3.31, \mathrm{SD}=0.59)$. There were no significant correlations between reading anxiety and the use of reading strategies. However, there is a significant difference between the levels of reading anxiety and the reading academic achievement among the participants. For the main effect of reading anxiety, the mean of reading achievement Low anxiety $(M=2.64$, $S D=0.50)$ was significantly larger than for High anxiety $(M=1.40, S D=0.52), p<.001$. From the findings of the study, it is suggested that teachers who prepared students for the test such as IELTS should provide more simulation tests so that students get familiar with the test-type questions. That would lower their level of anxiety for higher scores.

\section{Limitations of the study}

Firstly, the study was conducted at the International School of Thai Nguyen University, the sampling size is quite small $(\mathrm{N}=48)$. The findings, therefore, may not be well-generalized for all Vietnamese English language learners until other triangulation is made by further studies.

Secondly, the finding for research question 1 (RQ1) cannot be further analysed because the researcher adapted the questionnaire from another research.

\section{References}

Abbas, A. Z. (2014). The Effect of Reading Anxiety and Motivation on EFL Learners' Choice of Reading Strategies. Journal of Applied Linguistics and Language Research, 1(1), 12-28.

Abbott, M. L. (2006). ESL reading strategies: Differences in Arabic and Mandarin speaker test performance. Language Learning, 56(4), 633-670. https://doi.org/10.1111/j.1467-9922.2006.00391.x

Aida, Y. (1994). Examination of Horwitz, Horwitz, and 
Cope's construct of foreign language anxiety: The case of students of Japanese. The Modern Language Journal, 78(2), 155-167.

Anderson, N. J. (1991). Individual differences in strategy use in second language reading and testing. Modern Language Journal, 75(4), 460-472. https://doi.org/10.2307/329495

Anderson, N. J. (2005). L2 learning strategies. In E. Hinkel (Ed.), Handbook of research in second language teaching and learning (pp. 757-771). Mahwah, NJ: Lawrence Erlbaum.

Bates, D., Mächler, M., Bolker, B., \& Walker, S. (2014). Fitting linear mixed-effects models using lme4. Journal of Statistical Software, 67(1), 171-195. https://doi.org/10.18637/jss.v067.i01

Bell, L. C., \& Perfetti, C. A. (1994). Reading skill: Some adult comparisons. Journal of Educational Psychology, 86(2), 244-255.

Bohlmann, C., \& Pretorius, E. (2002). Reading skills and mathematics. South African Journal of Higher Education, 16(3), 196-206. https://doi.org/10.4314/ sajhe.v16i3.25232

Capan, A. S, \& Karaca, M. (2012). A comparative study of listening anxiety and reading anxiety. Procedia Social and Behavioral Sciences, 70(5), 1360-1373. https://doi.org/10.1016/j.sbspro.2013.01.198

Carrell, P. L. (1989). Metacognitive awareness and second language reading. The Modern Language Journal, 73(2), 121-134.

Carrell, P. L. (1998). Can reading strategies be successfully taught. Australian Review of Applied Linguistics, 21(1), 1-20.

Celce-Murcia, M. (2001). Teaching English as a second or foreign language. Boston, MA: Heinle and Heinle.

Chen, S. (2005). A study on the relationship between English reading anxiety and reading performance. Yantai Normal University Journal (Philosophy and Social Sciences Edition), 22(4), 99-101.

Cohen, J. (1988). Statistical power analysis for the behavioral sciences (2nd ed.). Hillsdale, NJ: L. Erlbaum Associates.

Conover, W. J., \& Iman, R. L. (1981). Rank transformations as a bridge between parametric and nonparametric statistics. The American Statistician, 35(3), 124-129.

Creme, P., \& Lea, M. R. (2008). Writing at university - A guide for students (3rd ed.). Berkshire: Open University Press.

Downing, J., \& Leong, C. K. (1982). Psychology of reading. New York, NY: MacMillan Publishing Corporation, Inc.

Farveh, N., Azadeh, N., \& Mohammad, M. M. (2014). The impact of foreign language reading anxiety and text feature awareness on university students' reading comprehension ESP texts. International
Journal of Language and Linguistics, 2(6-1), 1-7. https://doi.org/10.11648/j.ijll.s.2014020601.11

Field, A. (2013). Discovering statistics using SPSS (4th ed.). University of Sussex, UK: Sage Publications.

Gardner, R. C., \& MacIntyre, P. D. (1993). On the measurement of affective variables in second language learning. Language Learning, 43(2), 157194.

Ghonsooly, B. (2012). The Relationship between EFL Learners' Reading Anxiety Levels and Their Metacognitive Reading Strategy Use. International Journal of Linguistics, 4(3), 333-351.

Gunderson, L., D'Silva, A. R, \& Odo, M. D. (2014). ESL (ELL) Literacy Instruction - A Guide book to Theory and Practice. New York, NY: Routledge.

Gunning, T. G. (2007). Creating Literacy Instruction for all students (6th ed.). New York, NY: Pearson Education.

Haberlandt, K. F., \& Graesser, A. C. (1985). Component processes in text comprehension and some of their interactions. Journal of Experimental Psychology, 114(3), 357-374.

Horwitz, E. K., Horwitz, M. B., \& Cope, J. (1986). Foreign language classroom anxiety. The Modern Language Journal, 70(2), 125-132.

Janzen, J. (2002). Teaching Strategic Reading. TESOL Journal, 12(4), 287-293.

Johnston, P. H. (1983). Reading comprehension assessment: A cognitive basis. Newark, NJ: International Reading Association.

Just, M. A., \& Carpenter, P. A. (1992). A capacity theory of comprehension: Individual differences in working memory. Psychological Review, 99(1), 122-149.

Long, M. H., \& Crookes, G. (1992). Three approaclies to task-based syllabus design. TESOL Quarterly, 26(1), 27-56.

MacIntyre, P. D., \& Gardner, R. C. (1989). Anxiety and second language learning: Toward a theoretical clarification. Language Learning, 39(1), 251-275.

MacIntyre, P. D. (1999) Language Anxiety: A Review of the Research for Language Teachers. In D. J. Young (Ed.), Affect in foreign language and second language learning: A practical guide to creating a low-anxiety classroom atmosphere. Boston: McGraw-Hill.

Manoochehr, J. (2012). The Effect of Anxiety on Reading Comprehension among Distance EFL Learners. International Education Studies, 5(2), 159-174.

Martin, D., Martin, M., \& Carvalho, K. (2008). Reading and learning disabled children: Understanding the problem. The Clearing House, 81(3), 113-118.

Mokhtari, K., \& Sheorey, R. (2002). Measuring ESL students' awareness of reading strategies. Journal of Developmental Education, 25(3), 2-10.

Murad, M. A., Ismail, S. A, Mohamad, S. N., \& Zainurin, 
A. R. (2013). Foreign Language Reading Anxiety in a Jordanian EFL Context: A Qualitative Study. English Language Teaching, 6(6), 38-56.

Nagy, J., \& Habók, A. (2018). Attitudes and behaviours related to individual and classroom practices: An empirical study of external and internal factors of ICT use. Libri, 68(2), 113-124. https://doi. org/10.1515/libri- 2017-0099

Osborne, J., \& Waters, E. (2002). Four assumptions of multiple regression that researchers should always test. Practical Assessment, Research \& Evaluation, $8(2), 1-9$.

Oxford, R. (2001). Language Learning Styles and Strategies. In M. Celce-Murcia (Ed.), Teaching English as a Second or Foreign Language (pp. 359366). Boston, MA: Heinle and Heinle.

Paris, S. G., Wasik, B. A., \& Turner, J. C. (1991). The development of strategic readers. In R. Barr, M. L. Kamil, P. Mosenthal \& P. D. Pearson, (Eds.), Handbook of reading research (Vol. 2, pp. 609-640). Hillsdale, NY: Lawrence Erlbaum.

Qiu, M., \& Liao, F. (2007). Study on Chinese university students' foreign language reading anxiety. Journal of Xi'an International Studies University, 15(4), 5559.

Richard, C. J., \& Schmidt, R. (1985). Longman Dictionary of Language Teaching and Applied Linguistics. Edinburgh: Pearson.

Saito, Y., Garza, T. J., \& Horwitz, E. K. (1999). Foreign language reading anxiety. Modern Language Journal, 83(2), 202-218. https://doi. org/10.1111/0026-7902.00016

Sari, P. W. (2017). The relationship between reading anxiety and reading strategies used by EFL student teachers. Edukasi: Jurnal Pendidikan dan Pengajaran, 4(2), 1-9.

Schmidt, R. J., Rozendal, M., \& Greenman, G. (2002). Reading instruction in the inclusion classroom: Research-based practices. Remedial and special education, 23(3), 130-140.

Schumann, J. H. (1987). Where is cognition? Emotion and cognition in second language acquisition. Studies in Second Language, 16(2), 231-242.

Scovel, T. (1978). The effects of affect on foreign language learning: A review of anxiety research. Language Learning, 28(1), 129-142.

Sellers, V. (2000). Anxiety and reading comprehension in Spanish as a foreign language. Foreign Language Annals, 33(5), 572-521.

Shi, Y., \& Liu, Z. (2006). Foreign language reading anxiety and its relationship to English achievement and gender. Journal of PLA University of Foreign Languages, 29(2), 59-64.

Sparks, R. L., Ganschow, L., \& Javorsky, J. (2000). A response to Saito, Horwitz, and Garza. The Modern Language Journal, 84(2), 251-259.
Spielberger, C. D. (1976). The nature and measurement of anxiety. In C. D. Spielberger \& R. Diaz-Guerrero (Eds.), Cross-cultural anxiety (Vol. 1, pp. 3-12). Washington, DC: Hemisphere.

Tobias, S. (1979). Anxiety research in Educational Psychology. Journal of Educational Psychology, 71(5), 573-582.

Vann, R., \& Abraham, G. (1990). Strategies of Unsuccessful Language Learners. TESOL Quarterly, 24(2), 177-198. https://doi.org/10.2307/3586898

Walker, E. (1997). Foreign language anxiety in Hong Kong secondary schools: Its relationship with the age-related factors, school form and self-perception. Ph.D. dissertation, The University of Hong Kong.

Wang, Y., \& Fang, L. (2008). A study on the correlation among English reading anxiety, reading strategies, and reading performance. Journal of Chongqing University of Science and Technology (Social Sciences Edition), 9(5), 221-222.

Wardah, D. G., \& Jerryk, C. A. (2018). Reading Anxiety and Comprehension of Grade 8 Filipino Learners. International Journal of Humanities and Social Sciences, Special Volume, 44-59.

Westfall, P. H., \& Henning, K. S. S. (2013). Texts in statistical science: Understanding advanced statistical methods. New York, NY: Taylor \& Francis Group.

Williams, M., \& Burden, R. L. (1997). Psychology for language teachers: A social constructivist approach. London, UK: Cambridge University Press.

Wilta, P. (2017). The relationship between reading anxiety and reading strategies used by EFL student teachers. Edukasi: Jurnal Pendidikan dan Pengajaran, 4(2), 1-9.

Wu, J. H. (2013). Anxiety and Reading Comprehension Performance in English as a Foreign Language. Asian EFL Journal. 13(2), 273-307.

Young, D. J. (1986). The relationship between anxiety and Foreign Language oral proficiency ratings. Foreign Language Annals, 19(5), 439-445.

Yukselir, C. (2014). An investigation into the reading strategy use of EFL prep-class students. Procedia - Social and Behavioral Sciences, 15(8), 65-72. https://doi.org/10.1016/j.sbspro.2014.12.034

Zeidner, M. \& Matthews, G. (2010). Anxiety 101. New York, NY: Springer Publisher Company.

Zoghi, M. (2012). An Instrument for EFL Reading Anxiety: Inventory Construction and Preliminary Validation. The Journal of Asia TEFL, 9(1), 31-56. 


\section{APPENDICES}

\section{APPENDIX A: SURVEY OF READING STRATEGIES (SORS) (Mokhtari \& Sheorey, 2002)}

The purpose of this survey is to collect information about the various strategies you use when you read school-related academic materials in ENGLISH (e.g., reading textbooks for homework or examinations; reading journal articles, etc.). Each statement is followed by five numbers, 1, 2, 3, 4, and 5, and each number means the following:

means that 'I never or almost never do this'

means that 'I do this only occasionally'.

means that 'I sometimes do this' (about $50 \%$ of the time.)

means that 'I usually do this'.

means that 'I always or almost always do this'.

After reading each statement, circle the number (1, 2, 3, 4, or 5) which applies to you. Note that there are no right or wrong responses to any of the items on this survey.

\begin{tabular}{|c|c|c|c|c|c|c|}
\hline \# & STATEMENTS & \multicolumn{5}{|c|}{ RATING } \\
\hline 1. & I have a purpose in mind when I read. & 1 & 2 & 3 & 4 & 5 \\
\hline 2. & I take notes while reading to help me understand what I read. & 1 & 2 & 3 & 4 & 5 \\
\hline 3. & I think about what I know to help me understand what I read. & 1 & 2 & 3 & 4 & 5 \\
\hline 4. & I take an overall view of the text to see what it is about before reading it. & 1 & 2 & 3 & 4 & 5 \\
\hline 5. & When text becomes difficult, I read aloud to help me understand what I read. & 1 & 2 & 3 & 4 & 5 \\
\hline 6. & I this & 1 & 2 & 3 & 4 & 5 \\
\hline 7. & I read slowly and carefully to make sure I understand what I am reading. & 1 & 2 & 3 & 4 & 5 \\
\hline 8. & $\begin{array}{l}\text { I review the text first by noting its characteristics like length and } \\
\text { organization. }\end{array}$ & 1 & 2 & 3 & 4 & 5 \\
\hline 9. & I try to get back on track when I lose concentration. & 1 & 2 & 3 & 4 & 5 \\
\hline 10. & I underline or circle information in the text to help me remember it. & 1 & 2 & 3 & 4 & 5 \\
\hline 11. & I adjust my reading speed according to what I am reading. & 1 & 2 & 3 & 4 & 5 \\
\hline 12. & When reading, I decide what to read closely and what to ignore. & 1 & 2 & 3 & 4 & 5 \\
\hline 13. & I use reference materials (e.g. a dictionary) to help me understand what I read. & 1 & 2 & 3 & 4 & 5 \\
\hline 14. & When text becomes difficult, I pay closer attention to what I am reading. & 1 & 2 & 3 & 4 & 5 \\
\hline 15. & I use tables, figures, and pictures in text to increase my understanding. & 1 & 2 & 3 & 4 & 5 \\
\hline 16. & I stop from time to time and think about what I am reading. & 1 & 2 & 3 & 4 & 5 \\
\hline 17. & I use context clues to help me better understand what I am reading. & 1 & 2 & 3 & 4 & 5 \\
\hline 18. & I paraphrase (restate ideas in my own words) to better understand what I read. & 1 & 2 & 3 & 4 & 5 \\
\hline 19. & I try to picture or visualize information to help remember what I read. & 1 & 2 & 3 & 4 & 5 \\
\hline 20. & $\begin{array}{l}\text { I use typographical features like bold face and italics to identify key } \\
\text { information. }\end{array}$ & 1 & 2 & 3 & 4 & 5 \\
\hline 21. & I critically analyze and evaluate the information presented in the text. & 1 & 2 & 3 & 4 & 5 \\
\hline 22. & I go back and forth in the text to find relationships among ideas in it. & 1 & 2 & 3 & 4 & 5 \\
\hline 23. & rstanding when I come across new information. & 1 & 2 & 3 & 4 & 5 \\
\hline
\end{tabular}




\begin{tabular}{|c|c|c|c|c|c|c|}
\hline 24. & I try to guess what the content of the text is about when I read. & 1 & 2 & 3 & 4 & 5 \\
\hline 25. & When text becomes difficult, I re-read it to increase my understanding. & 1 & 2 & 3 & 4 & 5 \\
\hline 26. & I ask myself questions I like to have answered in the text. & 1 & 2 & 3 & 4 & 5 \\
\hline 27. & I check to see if my guesses about the text are right or wrong. & 1 & 2 & 3 & 4 & 5 \\
\hline 28. & When I read, I guess the meaning of unknown words or phrases. & 1 & 2 & 3 & 4 & 5 \\
\hline 29. & When reading, I translate from English into my native language. & 1 & 2 & 3 & 4 & 5 \\
\hline 30. & When reading, I think about information in both English and my & 1 & 2 & 3 & 4 & 5 \\
\hline
\end{tabular}

\section{SCORING GUIDELINES FOR THE SURVEY OF READING STRATEGIES}

Student Name:

Date:

Write the number you circled for each statement (i.e., 1, 2, 3, 4, or 5) in the appropriate blanks below.

Add up the scores under each column and place the result on the line under each column.

Divide the subscale score by the number of statements in each column to get the average for each subscale.

Calculate the average for the whole inventory by adding up the subscale scores and dividing by 30 .

Use the interpretation guidelines below to understand your averages.

\begin{tabular}{|c|c|c|c|}
\hline $\begin{array}{c}\text { GLOBAL READING } \\
\text { STRATEGIES } \\
\text { (GLOB Subscale) }\end{array}$ & $\begin{array}{c}\text { PROBLEM } \\
\text { SOLVING } \\
\text { STRATEGIES } \\
\text { (PROB Subscale) }\end{array}$ & $\begin{array}{l}\text { SUPPORT } \\
\text { READING } \\
\text { STRATEGIES } \\
\text { (SUP Subscale) } \\
\end{array}$ & $\begin{array}{c}\text { OVERALL } \\
\text { READING } \\
\text { STRATEGIES } \\
\text { (ORS) } \\
\end{array}$ \\
\hline 1 & 7 & 2 & \multirow[b]{2}{*}{ GLOB } \\
\hline 3 & 9 & 5 & \\
\hline 4 & 11 & 10 & \multirow[b]{2}{*}{ PROB } \\
\hline 6 & 14 & 13 & \\
\hline 8 & 16 & 18 & \multirow[b]{2}{*}{ SUP } \\
\hline 12 & 19 & 22 & \\
\hline 15 & 25 & 26 & \\
\hline 17 & 28 & 29 & \\
\hline 20 & & 30 & \\
\hline \multicolumn{4}{|l|}{21} \\
\hline \multicolumn{4}{|l|}{23} \\
\hline \multicolumn{4}{|l|}{24} \\
\hline \multicolumn{4}{|l|}{27} \\
\hline $\begin{array}{r}\text { GLOP Score } \\
/ 13 \\
\end{array}$ & $\begin{array}{c}\text { PROB Score } \\
18\end{array}$ & $\begin{array}{r}\text { SUP Score } \\
/ 9\end{array}$ & $\begin{array}{r}\text { Overall Score } \\
130 \\
\end{array}$ \\
\hline $\begin{array}{l}\text { GLOB } \\
\text { Average }\end{array}$ & PROB Average & SUP Average & Overall Average \\
\hline
\end{tabular}


KEY TO AVERAGES: 3.5 or higher $=$ High $2.5-3.4=$ Medium $\quad 2.4$ or lower $=$ Low

\section{INTERPRETING YOUR SCORES:}

The overall average indicates how often you use reading strategies when reading academic materials. The average for each subscale shows which group of strategies (i.e., Global, Problem Solving, or Support strategies) you use most often when reading. It is important to note, however, that the best possible use of these strategies depends on your reading ability in English, the type of material read, and your reading purpose. A low score on any of the subscales or parts of the inventory indicates that there may be some strategies in these parts that you might want to learn about and consider using when reading (adapted from Oxford, 1990, pp. 297-300).

Mokhtari, K., \& Sheorey, R. (2002). Measuring ESL students reading strategies. Journal of Developmental Education, $25(3), 2-10$.

\section{APPENDIX B: FOREIGN LANGUAGE READING ANXIETY SCALE (FLRAS)}

(Saito, Garza, \& Horwitz, 1999)
1: Strongly disagree
2: Disagree
3: Neutral
4: Agree
5: Strongly agree

\begin{tabular}{|c|c|c|c|c|c|c|}
\hline \# & STATEMENTS & \multicolumn{5}{|c|}{ RATING } \\
\hline 1. & $\begin{array}{c}\text { I get upset when I am not sure whether I understand what I am } \\
\text { reading in English }\end{array}$ & 1 & 2 & 3 & 4 & 5 \\
\hline 2. & $\begin{array}{l}\text { When reading English, I often understand the words, but still can't } \\
\text { quite understand what the author is saying. }\end{array}$ & 1 & 2 & 3 & 4 & 5 \\
\hline 3. & $\begin{array}{l}\text { When I am reading English, I get so confused that I can't remember } \\
\text { what I am reading. }\end{array}$ & 1 & 2 & 3 & 4 & 5 \\
\hline 4. & I feel intimidated whenever I see a whole page of English in front of me. & 1 & 2 & 3 & 4 & 5 \\
\hline 5. & $\begin{array}{l}\text { I am nervous when I am reading a passage in English when I am not } \\
\text { familiar with the topic. }\end{array}$ & 1 & 2 & 3 & 4 & 5 \\
\hline 6. & $\begin{array}{l}\text { I get upset whenever I encounter unknown grammar when reading } \\
\text { English. }\end{array}$ & 1 & 2 & 3 & 4 & 5 \\
\hline 7. & $\begin{array}{c}\text { When reading English, I get nervous and confused when I don't } \\
\text { understand every word. }\end{array}$ & 1 & 2 & 3 & 4 & 5 \\
\hline 8. & $\begin{array}{l}\text { It bothers me to encounter words I can't pronounce while reading } \\
\text { English. }\end{array}$ & 1 & 2 & 3 & 4 & 5 \\
\hline 9. & I usually end up translating word by word when I am reading English. & 1 & 2 & 3 & 4 & 5 \\
\hline 10. & $\begin{array}{l}\text { By the time I get past the funny letters and symbols in English, it is } \\
\text { hard to remember what I've read about. }\end{array}$ & 1 & 2 & 3 & 4 & 5 \\
\hline 11. & $\begin{array}{l}\text { I am worried about all the new symbols I have to learn in order to read } \\
\text { in English. }\end{array}$ & 1 & 2 & 3 & 4 & 5 \\
\hline 12. & I enjoy reading English & 1 & 2 & 3 & 4 & 5 \\
\hline 13. & I feel confident when I am reading in English & 1 & 2 & 3 & 4 & 5 \\
\hline 14. & Once I get used to it, reading English is not so difficult. & 1 & 2 & 3 & 4 & 5 \\
\hline 15. & The hardest part of learning English is learning to read. & 1 & 2 & 3 & 4 & 5 \\
\hline 16. & $\begin{array}{l}\text { I would be happy just to learn to speak English rather than having to } \\
\text { learn to read as well. }\end{array}$ & 1 & 2 & 3 & 4 & 5 \\
\hline
\end{tabular}




\begin{tabular}{|c|c|c|c|c|c|c|}
\hline 17. & $\begin{array}{c}\text { I don't mind reading to myself, but I feel very uncomfortable when I } \\
\text { have to read in English. }\end{array}$ & 1 & 2 & 3 & 4 & 5 \\
\hline 18. & $\begin{array}{c}\text { I am satisfied with the level of reading ability in English that I have } \\
\text { achieved so far. }\end{array}$ & 1 & 2 & 3 & 4 & 5 \\
\hline 19. & English culture and ideas seem very foreign to me. & 1 & 2 & 3 & 4 & 5 \\
\hline 20. & $\begin{array}{c}\text { I have to know so much about English history and culture in order to } \\
\text { read English. }\end{array}$ & 1 & 2 & 3 & 4 & 5 \\
\hline
\end{tabular}

KEY TO AVERAGES:

3.5 or higher $=$ High anxiety level; $2.5-3.4=$ Medium anxiety level; 2.4 or lower $=$ Low anxiety level

\title{
MỐI QUAN HỆ GIŨ̉A NỖI LO LẮNG TRONG KHI ĐỌC, VIẸC SỬ DỤNG CÁC CHIẾN LƯợC VÀ KẾT QUẢ MÔN ĐỌC HỌC THUẠTT CỦA SINH VIÊN KHÔNG CHUYÊN TIẾNG ANH TẠI MỘT TRƯờnG ĐẠI HỌC Ở PHÍA BẮC VIỆT NAM
}

\author{
Lê Quang Dũng \\ Khoa Quốc tế, Đại học Thái Nguyên \\ Phường Tân Thịnh, Thành phố Thái Nguyên, Việt Nam
}

Tóm tắt: Nghiên cứu định lượng này được tiến hành tại Khoa Quốc tế, Đại học Thái Nguyên nhằm tìm ra mức độ lo lắng khi làm bài đọc học thuật của sinh viên không chuyên ngữ. Những sinh viên này vừa kết thúc một khóa tiếng Anh tăng cường và sẽ phải thi một bài thi mô phỏng theo dạng thức bài thi IELTS (bài thi học thuật). Các sinh viên này bắt buộc phải đạt trình độ $\mathrm{B} 2$ chuẩn Châu Âu (5.5) để được xét vào học chuyên ngành. Kết quả nghiên cứu cho thấy, mức độ lo lắng trong khi làm bài đọc ở mức trung bình $(\mathrm{M}=$ $3.31, \mathrm{SD}=0.59$ ). Nghiên cứu cho thấy không tồn tại mối tương quan giữa mức độ lo lắng và việc sử dụng các chiến lược trong khi làm bài đọc. Kết quả nghiên cứu cũng chỉ ra mối quan hệ tỷ lệ nghịch giữa mức độ lo lắng cao với kết quả bài thi môn đọc $($ Low $(\mathrm{M}=2.64, \mathrm{SD}=.49)$ and High $(\mathrm{M}=1.40, \mathrm{SD}=.52))$. Càng lo lắng thì kết quả càng thấp.

Từ khóa: mối quan hệ, nỗi lo lắng khi đọc, chiến lược đọc, lo lắng ở mức cao, kết quả thấp. 